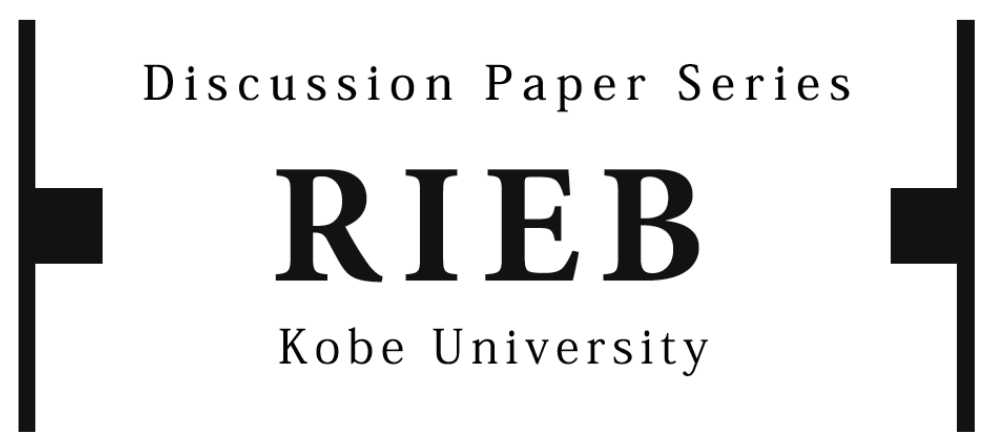

\title{
When Organizational Justice Matters for Affective Merger Commitment*
}

\section{Ralf BEBENROTH \\ Kai Oliver THIELE}

June 3,2015

* The Discussion Papers are a series of research papers in their draft form, circulated to encourage discussion and comment. Citation and use of such a paper should take account of its provisional character. In some cases, a written consent of the author may be required.

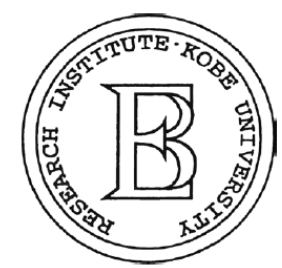

Research Institute for Economics and Business Administration Kobe University 
When Organizational Justice Matters for Affective Merger Commitment

Corresponding author

Ralf Bebenroth

Kobe University

Research Institute for Economics and Business Administration

657-8501 Kobe-shi, Nada-ku, Rokko-dai 2-1 Japan

Phone: +81 78 803-7021

Fax: +8178 803-7021

E-mail: rbeben@rieb.kobe-u.ac.jp

Kai Oliver Thiele

Hamburg University of Technology (TUHH)

Human Resource Management and Organizations (HRMO)

Schwarzenbergstraße 95 (D)

21073 Hamburg

Germany

Phone: +49 40428783772

Fax: +49 40428784471

E-mail: k.thiele@tuhh.de 


\title{
When Organizational Justice Matters for Affective Merger Commitment
}

\begin{abstract}
We investigate when organizational justice matters to employees' commitment in the post-acquisition process after a company is overtaken in a cross-border acquisition. There is overwhelming evidence that employees who are treated fairly during acquisitions are more committed to their new firms. We extend this finding by dividing organizational justice into three sub-dimensions: informational justice, interpersonal justice, and procedural justice. We find evidence that procedural justice is an important antecedent of affective merger commitment at an early stage of the integration period, while informational justice becomes important at a later stage.

Further analysis on heterogeneity between the target firm's employees and the bidder firm's employees reveals that, immediately after the acquisition, target-firm's employees value knowing where they will be at the new firm (procedural justice), while bidder-firm employees are more concerned about communication and transparency (informational justice). Our results point to the importance of organizational justice in a cross-border M\&A setting and the need for a separate study of issues related to bidder firms and target firms.
\end{abstract}

Keywords: Organizational Justice, Informational Justice, Interpersonal Justice, Procedural Justice, Affective Merger Commitment. 


\section{Introduction}

Firms seek to create value through mergers and acquisitions (M\&As) that allow them to acquire new technologies, diversify their portfolios, or enter foreign markets (Faulkner, Teerikangas, \& Joseph, 2012). Cross-border deals in particular have become a popular strategy for helping firms remain competitive in global markets. Even companies from emerging markets bid for western targets (Boateng, Qian, \& Tianle, 2008; Chatzkel \& Ng, 2013).

Although there have been numerous attempts to determine how to undertake the integration process (e.g., Ellis et al. 2009; Senn, 2008), failure to generate the desired added value remains common, as either the acquisition fails financially in that it does not generate the desired returns, or eventually the strategic intentions of the management cannot be met (Dauber, 2009; Knilans, 2009). Cartwright and Schoenberg (2006) report that the overall success rate of cross-border deals is usually less than 50 percent, an unpleasant phenomenon that has been widely discussed in literature. While research on M\&As has originated in finance and strategic management, these research areas have not yet fully explained the driving forces behind the success or failure of a merger or acquisition. For that reason, focus has shifted toward the human side of the equation, with a majority of articles published after the year 2000 addressing the human factor (Mirc, 2014).

Not surprisingly, M\&A leads to human integration problems; it is the rare CEO who does not mention the human factor as critical during the course of a merger. The target firm's employees are often in the difficult situation of adjusting to the buyer firm, and many companies even restructure, making the adjustment all the more challenging. Target employees may fear having to get out of their routines or may expect to be laid off. The resulting anxiety causes some employees to enter a largely unproductive, passive mode of working, while employees with high potential leave the firm. 
Employees from the bidder firm can also be affected negatively since they often need to build new teams of both bidder and target employees (Appelbaum, Serena, \& Shapiro, 2004). Even if future working conditions are generally set up to be fruitful and positive, employees may anticipate difficulties, which leads to decreased commitment and other issues.

A successful acquisition must take employees’ feelings into consideration and win their commitment to the M\&A process, so we study the "human side of M\&A" by investigating how employees’ perceptions of justice affect their affective commitment to the merger or acquisition. While other researchers have focused on behavioral outcomes like identification or satisfaction (Dick, Ullrich, \& Tissington, 2006), we focus on the affective merger commitment (AMC) by adapting items from Herscovitch and Meyer (2002) (e.g., "I believe in the value of this affiliation”).

Several studies have analyzed the role of justice as a source of value creation in the course of an acquisition (e.g., Ellis, Reus, \& Lamont, 2009) or on managerial commitment (Klendauer \& Deller, 2009). Other studies have investigated how subdimensions of justice are mediated by a latent variable for overall justice that affects commitment (e.g., Ambrose \& Schminke, 2009; Jones \& Martens, 2009; Marzucco, Marique, Stinglhamber, De Roeck, \& Hansez, 2014). In fact, the discussion of and research on an overall justice construct represents a paradigm shift in justice research, which had once focused primarily on justice’s sub-dimensions (Ambrose \& Schminke, 2009). The inclusion of such a global construct is advantageous since it empowers researchers to measure the impact of justice as a single antecedent on individual psychological constructs (e.g., commitment, job satisfaction). One way of implementation is to operationalize it as a higher order construct (HOC), where we see three primary advantages: First, as Colquitt and Shaw (2005) state, the approach is particularly appealing in reactive field studies with multiple events or an entity context, 
such as ours. Second, other merger research finds that sub-dimensions have a relatively low explanatory power on overall justice (e.g., $R^{2}=.33$ in Ambrose \& Schminke, 2009). Since overall justice captures all of justice’s sub-dimensions, we expect a higher explained variance, so we infer that the current state of measurement of overall justice is insufficient for our research objective. Third, we see additional value in incorporating overall justice as a formatively modeled HOC. In the past, researchers have focused on modeling overall justice reflectively as a second-order construct (e.g., Judge \& Colquitt, 2004), neglecting the fact that the sub-dimensions "form" overall justice (MacKenzie, Podsakoff, \& Jarvis, 2005) and not the other way around. By incorporating justice as a HOC in our research, we can gauge the importance of each sub-dimension's importance in the formation of organizational justice.

Thus, our research is innovative in (i) focusing on employees' AMC, as we focus not only on commitment to the new firm, as Klendauer and Deller (2009) do, but to the commitment of the merger process itself from the employees' point of view. The research is also innovative in (ii) separating organizational justice into the three most relevant sub-dimensions for affective merger commitment (AMC) and applying structural equation modeling to model organizational justice formatively as a HOC. Innovation is also offered in (iii) comparing the perceptions of two intuitively distinct but rarely separately studied groups: the bidder-firm employees and the target-firm employees. Seo and Hill (2005) and Viegas-Pires (2013) also point to the importance of the dynamic nature of integration processes, so we innovate in (iv) including observations made at three times following the post-merger integration process: immediately after the deal is made, six months later, and about six month after that. Furthermore, (v) there is still a need for an extension of empirical studies using quantitative methods, since the majority of research on the impact of humans on mergers relies on qualitative approaches (e.g., case studies) (Mirc, 2014), perhaps 
because of the significant barriers from the corporate side to let researchers participate in an acquisition process.

The remainder of this article is structured as follows. First, we build our research on the organizational justice theory, which has its origins in Adams’ equity theory (1963; 1965). We then define the sub-dimensions of organizational justice and AMC and develop some testable hypotheses. Next, we analyze our data by using partial least squares structural equation modeling, which has seen significant growth in social science research recently (e.g., Hair, Sarstedt, Pieper, \& Ringle, 2012). Finally, we discuss our results, highlight our recommendations for researchers and practitioners and enumerate our study’s limitations.

\section{Theory Development and Hypotheses}

Researchers define justice (or fairness) based on whether an action or decision is morally right and promotes equality between group members. In business research, organizational justice theory integrates justice into the context of a corporate work environment, focusing on the employees’ assessment of their surroundings. Specifically, it provides conceptual insights into employees’ psychological behaviors in response to managerial decisions. Past research has shown that organizational justice is an antecedent of outcome-related psychological factors like job satisfaction and organizational commitment (Cohen-Charash \& Spector, 2001).

The concept of organizational justice originated in the equity theory developed by Adams (1963; 1965), who investigated what we refer to as distributional justice, where one’s evaluation of fairness stems from a subjective comparison of inputs against outcomes. In this logic, input refers to what a person perceives that he or she contributes, such as knowledge or effort, and outcome is what individuals receive in exchange, such as pay or recognition. In general, people first evaluate what they invest and what they received as compensation. Following this initial “calculation,” they compare their value 
against that of others (e.g., members of their peer group). In response, they may alter their employee's behavior in the workplace and perhaps their job motivation or organizational commitment. Adams' theoretical framework for justice perceptions in legal entities has been studied extensively over the last half century, and researchers have explored alternative sub-dimensions of organizational justice (Colquitt, Conlon, Wesson, Porter, \& Ng, 2001). Today, the consensus is that organizational justice consists of: (a) distributive justice, which is the original concept of organizational justice that deals with fairness of outcomes, such as pay, rewards, and promotions; (b) procedural justice, which is concerned with procedures, such as whether employees have a say in and are involved in the processes (Thibaut \& Walker, 1975); and (c) interactional justice, which deals with the general treatment of organizational members, such as being treated with dignity by the new management (Colquitt, Greenberg, \& Zapata-Phelan, 2005). Colquitt (2001) also finds evidence that researchers should split interactional justice into two dimensions: interpersonal justice, which refers to the general treatment of people, and (d) informational justice, which refers to how important members of organizations value adequate and timely information. Especially during the post-integration period of a merger, it is particularly important to have the employees' support not only for the new firm but also for the merger process itself. Theory on what drives employees’ commitment to a merger is scarce (e.g., Chawla \& Kelloway, 2004; Rafferty \& Restubog, 2009) but should answer the question concerning what an employee needs in order to argue in favor of the merger. A suitable construct for the “merger commitment” can be deduced from previous work on organizational commitment, a widely studied construct popular in human resource management research (Mowday, Steers, \& Porter, 1979), but merger commitment must be distinguished from organizational commitment in that it should not capture the commitment to the (new) organization but to the merger process itself. In other words, 
merger commitment is a commitment to change rather than a commitment to an entity or institution. In this regard, Herscovitch and Meyer (2002) suggest an adaption of the original three-component model for organizational commitment (Meyer \& Allen, 1991) — which consists of the three sub-dimensions: affective commitment, continuance commitment, and normative commitment—-to organizational change processes.

Following this logic, merger processes can be seen as special cases of organizational change processes. Researchers have found affective commitment to be the key subdimension of organizational commitment and have focused on it in their research (Purba et al., 2015; Buitendach \& Witte, 2005; Rafferty \& Restubog, 2009). Similar approaches have been observed in research on affective commitment during mergers (e.g., Ambrose \& Schminke, 2009). In the organizational change context, Herscovitch and Meyer (2002, p. 475) define affective commitment as “a desire to provide support for a change based on a belief in its inherent benefits," which is essentially the construct that we are interested in and that we want to adapt to a merger context. Therefore, we develop the construct affective merger commitment (AMC), which is operationalized with three items (Table 2).

We see the organizational justice construct as a valuable explanatory factor that drives employees’ AMC. Specifically, we seek to clarify how the effect of organizational justice on AMC changes as the acquisition process advances. Based on the idea that the sub-dimensions of justice have more or less importance during the course of a merger, we can assume that organizational justice's impact on employees' AMC varies as time passes. Thus, the relationship between these two constructs is not static but is a dynamic process in which employees’ needs change over time according to changing psychological needs (Seo \& Hill, 2005). Therefore, we are interested in the employees' perceptions at the informational, interpersonal, and procedural justice levels of how they are treated by the management. However, we do not investigate distributive 
justice, over which we assume the new management has only limited control. For example, whether there are income differences between employees of the target firm and the bidder firm may not be directly attributable to the new management because, in a cross-border deal, the management in the target firm's country takes the leading role (and the responsibility in case of a failure), but the headquarters may decide on distributive criteria like salary adjustments. Furthermore, employees from the target firm may not automatically receive the work conditions of the bidder firm but may continue with their existing conditions. To unveil differences between these two employee groups, we also perform an analysis on heterogeneity between bidder employees' and target employees’ perceptions.

Employees should value informational justice more at the beginning of the acquisition than later (Citera \& Rentsch, 1993) because the beginning is when uncertainty is highest and employees are likely to want sufficient and timely information (Ellis et al., 2009). Both groups of employees—-those from the target firm and those from the bidder firm—should value receiving timely, precise, and thorough information. With the perception that they have received such information, their AMC should be high. Procedural justice should also have a high value at the beginning of an acquisition because employees on both sides of the acquisition want to know about their positions at the new firm before they can have AMC (Ellis et al., 2009). In contrast, interpersonal justice should matter at a later stage. Fair treatment is an important part of gaining employees’ commitment, as Jones and Martens (2009), who investigate employees’ perceptions four years after the merger, find. From these observations, we deduce the three major parts of hypotheses that guide our study: 
Hypothesis H1: Employees’ perceptions of organizational justice correlate positively to their AMC.

Hypothesis H2: Sub-dimensions of justice change over time in its importance to affect AMC. Hypothesis H2.1: Procedural justice affects AMC positively more right after the acquisition than later.

Hypothesis H2.2: Informational justice affects AMC positively more right after the acquisition than later.

Hypothesis H2.3: Interpersonal justice affects AMC more at a later stage than at an earlier stage.

Hypothesis H3.1: Employees from the bidder firm seek more informational justice at the beginning of the acquisition than later.

Hypothesis H3.2: Employees from the target firm seek more procedural justice at the beginning of the acquisition than later.

The structural model we propose is presented in Figure 1, with organizational justice modeled as a HOC and time as a moderating variable.

Figure 1: Structural model with organizational justice as a HOC

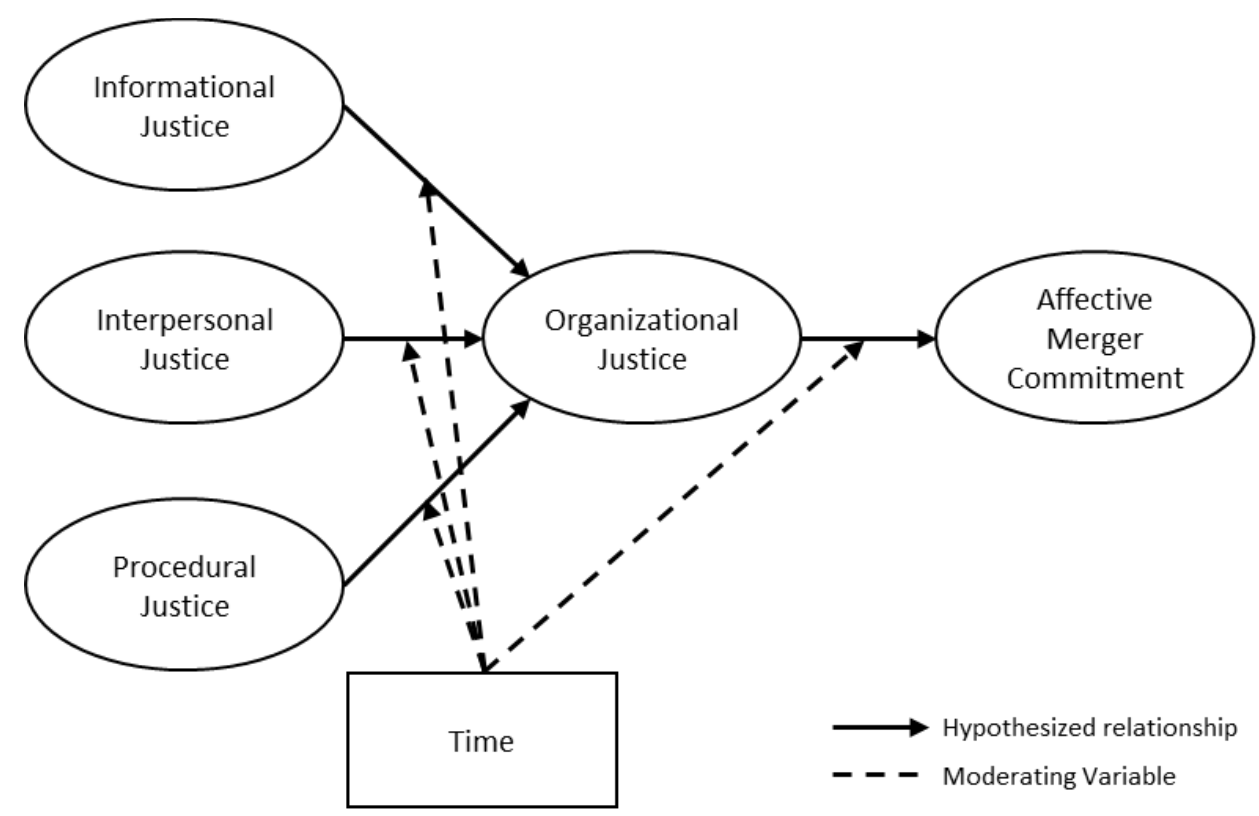


In the following sections we will test our research hypotheses in an empirical study in a cross-border setting.

\section{Empirical Analysis}

\subsection{Construct Measures}

We operationalize organizational justice as a HOC and follow prior studies in analyzing its corresponding sub-dimensions. A HOC is a latent variable that consists of several sub-dimensions (Becker, Klein, \& Wetzels, 2012). For organizational justice these subdimensions are informational justice, interpersonal justice, and procedural justice. Each sub-dimension is operationalized by four reflectively measured items. We use a fivepoint Likert scale based on Colquitt (2001) for the items since they have a fair level of discriminant validity and are theoretically sound (Table 2). We operationalize AMC with a reflective three-item, five-point Likert scale for affective commitment to organizational change, adapted from Herscovitch and Meyer (2002). Herscovitch and Meyer derive their measurement models from Meyer and Allen (1991), who develop a three-component model of organizational commitment that contains affective, continuance, and normative commitment. The measurement of organizational commitment in human resource management has a long history (e.g., Mowday et al., 1979), from which researchers have discovered that affective commitment is suggested to predict performance better than the other dimensions do (Allen \& Meyer, 1996;

Meyer et al., 2002). Therefore, social scientists have focused on affective commitment in the single-entity context (e.g., Buitendach \& Witte, 2005) as well as in the merger context (Ambrose \& Schminke, 2009). We follow that research stream in transferring affective commitment to the post-integration process of M\&A and call it AMC, which we measure with an adapted version of the affective commitment to change scale from Herscovitch and Meyer (2002) (Table 2). 


\subsection{Sample}

In the sample used throughout the present study, the bidder, a Japan-based German subsidiary in the technical testing device industry, is knowledgeable about the host country, Japan, and enjoys a high degree of autonomy from its German headquarters. The leading executive manager of the Japan-based German subsidiary, who became the leading manager at the new firm, is not only German but has also been living in Japan for many years and speaks fluent Japanese. Several other managers at the German subsidiary are also non-Japanese but are equipped with considerable knowledge about Japan. Even the Japanese managers at the German bidder firm have worked at the subsidiary, often for many years, and they have been influenced to a high degree by the German culture. In short, this sample has realistic characteristics because of the bidder's level of knowledge about the target country. Thus, our research design is realistic because of the increase in cross-border bidders' knowledge about markets in which they have already operated for a long time. As the number of cross-border M\&As has been increasing for many years, our sample provides a realistic scenario of a bidder firm that is familiar with the target country.

We administered the survey in three rounds $\left(t_{1}, t_{2}, t_{3}\right)$ in English and in Japanese. The Japanese version was back-translated by two professionals, and all items with translation irregularities were discussed and adjusted accordingly. The top management of the newly established Germany-based company in Japan distributed a link to the internet-based questionnaire among bidder and target employees. We conducted the first survey round $\left(t_{1}\right)$ in July 2012, shortly after the official announcement of the acquisition. A second round $\left(t_{2}\right)$ of distribution took place almost half a year later, in December 2012. At that time some strategic changes were implemented at the target firm when some of the business moved to the bidder firm and other parts of the business moved to the target firm. For example, one new machine purchased for testing bigger 
devices was not placed at the bidder firm, but at the previous target firm. Some other product lines for testing devices were also moved in order to realize synergies not only to the bidder firm but also to the target firm. The third round $\left(t_{3}\right)$ of the survey was collected in August 2013, about a year after the transaction took place. Before each survey round, the leader of the German subsidiary and the previous owner of the Japanese target firm personally reminded both groups of employees to participate in the survey. We also sent reminders to all employees.

At $\left(t_{1}\right)$, we collected 52 usable respondents for this research study from a potential total of 72 target employees and 34 responses from about 120 bidder employees. Follow-up interviews conducted by the first author revealed that the previous Japanese owner, whom the Japanese target employees still highly respected, had personally requested that the employees participate at the survey. At $\left(t_{2}\right)$, we collected 59 responses from the target employees and 38 from the bidder employees, while at $\left(t_{3}\right)$, we received 57 responses from the target and 49 from the bidder. Followup interviews revealed that the German top manager had requested, especially at $\left(t_{3}\right)$, that the (bidder firm) employees participate with all efforts in order to have meaningful results and reveal how they perceived the acquisition. 
Table 1: Sample description

\begin{tabular}{|c|c|c|c|c|c|c|c|c|c|c|c|}
\hline & & Irg & & & & & & & & & vera \\
\hline Firm-years & dere & & Overall & Age category & der' & get & erall & Gender & Bidderet & & \\
\hline round $1\left(t_{1}\right)$ & 34 & 52 & 86 & round $1\left(t_{1}\right)$ & 34 & 52 & 86 & round $1\left(t_{1}\right)$ & 34 & 52 & 86 \\
\hline under 1 & 7 & 5 & 12 & $<30$ years & 2 & 15 & 17 & male & 20 & 44 & 64 \\
\hline under 5 & 13 & 9 & 22 & $31-40$ years & 14 & 18 & 32 & female & 11 & 7 & 18 \\
\hline under 10 & 8 & 16 & 24 & $41-50$ years & 13 & 17 & 30 & missing & 3 & 1 & 4 \\
\hline under 15 & 4 & 11 & 15 & 51-60 years & 3 & 2 & 5 & & & & \\
\hline over 16 & 0 & 11 & 11 & missing & 2 & 0 & 2 & & & & \\
\hline missing & 2 & 0 & 2 & & & & & & & & \\
\hline round $2\left(\mathrm{t}_{2}\right)$ & 38 & 59 & 97 & round $2\left(\mathrm{t}_{2}\right)$ & 38 & 59 & 97 & round $2\left(\mathrm{t}_{2}\right)$ & 38 & 59 & 97 \\
\hline under 1 & 6 & 4 & 10 & $<30$ years & 1 & 18 & 19 & male & 19 & 47 & 66 \\
\hline under 5 & 16 & 10 & 26 & $31-40$ years & 14 & 21 & 35 & female & 14 & 12 & 26 \\
\hline under 10 & 7 & 23 & 30 & $41-50$ years & 16 & 18 & 34 & missing & 5 & & 5 \\
\hline under 15 & 3 & 12 & 15 & 51-60 years & 3 & 2 & 5 & & & & \\
\hline over 16 & 1 & 10 & 11 & missing & 4 & 0 & 4 & & & & \\
\hline missing & 5 & 0 & 5 & & & & & & & & \\
\hline round $3\left(\mathrm{t}_{3}\right)$ & 49 & 57 & 106 & round $3\left(t_{3}\right)$ & 49 & 57 & 106 & round $3\left(t_{3}\right)$ & 49 & 57 & 106 \\
\hline under 1 & 9 & 5 & 14 & $<30$ years & 2 & 19 & 21 & male & 26 & 46 & 72 \\
\hline under 5 & 19 & 12 & 31 & $31-40$ years & 22 & 19 & 41 & female & 20 & 10 & 30 \\
\hline under 10 & 12 & 16 & 28 & $41-50$ years & 18 & 17 & 35 & missing & 3 & 1 & 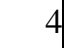 \\
\hline under 15 & 5 & 11 & 16 & 51-60 years & 4 & 2 & 6 & & & & \\
\hline over 16 & 1 & 13 & 14 & $>61$ years & 1 & 0 & 1 & & & & \\
\hline missing & 3 & 0 & 3 & missing & 2 & 0 & 2 & & & & \\
\hline
\end{tabular}

Notes: Three rounds of questionnaire results, divided in firm years, age and gender

\subsection{Estimation Procedure}

For the estimation procedure, we used partial least squares structural equation modeling (PLS-SEM; Hair, Sarstedt, Ringle, \& Mena, 2012) and SmartPLS 3 (Ringle, Wende, \& Becker, 2015). PLS-SEM (Wold, 1973) has recently gained attention in social science research in disciplines like strategic management (Hair et al., 2012; Hulland, 1999) and marketing research (Hair, Ringle, \& Sarstedt, 2011b; Henseler, Ringle, \& Sinkovics, 2009). Unlike its counterpart CB-SEM (Jöreskog, 1982), PLS is advantageous in exploratory research situations where only a little is known about the relationship between the underlying variables (Hair, Ringle, \& Sarstedt, 2011a, p. 14). It can also be used to estimate HOCs like organizational justice formatively (e.g., Wilson, 2010), and it is the preferable multivariate analysis method with sample sizes smaller than 250 observations (Chin \& Newsted, 1999; Reinartz, Haenlein, \& Henseler, 2009). Therefore, PLS-SEM is the preferable research method in our setting. In order to estimate the HOC of organizational justice, we followed existing guidelines (Becker et al., 2012) and 
estimated the model using PLS Mode B since this procedure has been shown to recover the real parameter values most effectively. Modeling HOC like organizational justice with structural equation modeling is a novel approach that has gained recent attention (e.g., Cheung, 2008). Specifically, by implementing the lower-order constructs (LOCs) into the model, we can gauge the sub-dimensions’ partial impact on organizational justice and evaluate whether the relationship between organizational justice and AMC changes over time or remains stable. Finally, to test our model for significant differences between bidder and target employees, we applied a multi-group analysis (MGA) approach (PLS-MGA; Keil et al., 2000).

\section{Results}

\subsection{Overall Model Results}

We first evaluated the overall model with regard to the generally recommended quality criteria for PLS-SEM. As suggested in the literature (e.g., Hair, Hult, Ringle, \& Sarstedt, 2014), we started by evaluating the measurement models for the overall sample of bidder and target employees (Table 5). All constructs were measured reflectively, and the loadings are well above the threshold of .7. We also have a high level of internal consistency since the composite reliability (CR) and Cronbach's $\alpha$ are well above .7 for all exogenous and endogenous constructs. Finally, for all points in time, the average variance extracted (AVE) for all constructs is above the threshold of .5, indicating that each construct explains at least 50 percent of its indicator variance. The Fornell-Larcker criterion (Fornell \& Larcker, 1981) is satisfied since the square root of the AVE of all reflectively measured latent variables is larger than the correlation with other latent 
variables ${ }^{1}$. Therefore, discriminant validity is established and all constructs measure different phenomena.

In evaluating the HOC of organizational justice, we followed Becker et al., (2012) and treated the path coefficients of the LOCs as weights. Investigating the relationship of the LOCs with the HOC showed no multi-collinearity issues since the variance inflation factor (VIF) is well below the critical value of 5 . Thus, we can interpret the path coefficients in order to validate our research hypotheses. We confirm previous research results with $\mathrm{H} 1$ that a higher justice on average leads to a better AMC (Marzucco et al., 2014; Table 4).

Next, we assess the explained variance of the model, the paths evaluation in the structural model, and their predictive relevance (Table 4). Overall, we find that our model can explain a fair amount of variance in the target construct, AMC, with the highest $R^{2}$ at .37. The model results also indicate that the relationship between organizational justice and AMC is stable over time, with path-coefficients ranging from .53 to .61. Therefore, we conclude that the importance of organizational justice remains comparatively stable over time. We generate substantial $Q^{2}$ values well above .2, showing the model's applicability for prediction. Therefore, our model works well with the given sample and can also be justified for use when performing out-ofsample calculations, making it especially useful for prediction in practical applications.

We also find differences in the importance of all LOCs over time, which supports hypothesis $\mathrm{H} 2$ that the justice sub-dimensions affect AMC differently. As shown in Table 3, starting with $t_{1}$, we find evidence that at the first round procedural justice, with a path-coefficient of .85, is the most important factor in employees’ perceiving organizational justice. This result is also clearly supported by the $f^{2}$ value of 18.51, which indicates the importance of each exogenous construct in explaining

\footnotetext{
${ }^{1}$ Correlation matrices are provided by the authors upon request.
} 
variance in organizational justice. Over time, however, the strength of procedural justice diminishes such that it is no longer significant in $t_{3}$. Thus, higher procedural justice affects AMC more right after the acquisition than later, which supports our hypothesis H2.1. In contrast, informational justice and interpersonal justice have no significance and had low $f^{2}$ values in the first round $\left(t_{1}\right)$. However, the importance of informational justice increases over time, from .26 in $t_{1}$ to .47 in $t_{2}$ and .64 in $t_{3}$, where the last two observations are significant, not supporting hypothesis H2.2. Across all three estimated rounds $\left(t_{1}\right.$ to $\left.t_{3}\right)$ interpersonal justice has the lowest impact of all LOCs, in $t_{2}$ even showing a negative path coefficient, thus, not confirming hypothesis H2.3.

\subsection{Multi-Group Analysis (MGA)}

After showing that the model meets the required quality criteria, we analyze how organizational justice correlates to AMC and analyze the heterogeneity of bidder and target employees in an a priori segmentation. The results of the MGA are presented in Table 6 and Table 7. We proceeded as follows: Unless for $t_{1}$ the path coefficients for both groups are simultaneously (non-) significant, we can neglect the parametric test for group differences (Keil et al., 2000). In the remaining cases, we reveal group differences by means of ordinary F-tests.

Our findings show that organizational justice strongly correlates with AMC and that it continues to do so even a year after the acquisition. We investigate three rounds $\left(t_{1}, t_{2}, t_{3}\right)$ for heterogeneity. Shortly after the public announcement in $t_{1}$, we find that informational justice is critically important for the bidder employees to show AMC, with a path-coefficient of .87, whereas procedural justice is not significant (Table 6). Thus, bidder employees value informational justice highly at the first and the third survey round, supporting our hypothesis H3.1. 
In contrast, the target employees at $t_{1}$ seek procedural justice, revealed in a path coefficient of 1.21, while at the same time the role of informational justice is negligible. In $t_{2}$ procedural justice is significant for target employees until its effect vanishes in $t_{3}$. Therefore, in $t_{2}$ procedural justice remains important for target employees, supporting mainly hypothesis H3.2. The role of informational justice shows changing importance depending on the phase.

The effect of interpersonal justice is generally not significant; its estimated effects may even change directions, indicating that interpersonal justice is the weakest and most volatile of the LOCs.

\section{Discussion and Conclusions}

The goal of this study is to determine how employees' justice perceptions affect their AMC immediately after acquisition announcement had taken place until about one year later. Based on the equity theory and on the construct of AMC during change processes, we developed hypotheses and incorporated them into a dynamic process by linking constructs like justice and AMC over time. We tested our hypotheses against the data from three survey rounds ( $t_{1}$ to $t_{3}$ ) conducted during the acquisition of a Japanese company by a German subsidiary in Japan. Our results suggest that organizational justice and its three sub-dimensions link positively to the employees’ AMC, accompanied by a high level of explained variance, suggesting that, during a merger, employees will show support for the merger if they are treated fairly. The importance of justice in the sense of a HOC remained constant for all survey rounds, indicating that there is always a relatively stable psychological demand for organizational justice among employees, even in later phases of the acquisition. This result is important, as it emphasizes that the need for organizational justice does not diminish as the postintegration process ages. 
Furthermore, an observable shift in the justice sub-dimensions occurs as time passes. The importance of procedural justice for the new firm (with all employees involved) is highest at the beginning of an acquisition and decreases over time. Shortly after an acquisition, employees focus on procedural matters (Ellis et al., 2009), while the importance of procedural justice diminishes after the acquisition, replaced by informational justice, which becomes gradually more important in later stages of the acquisition. Thus, while employees are initially interested in their new roles, when their personal job security is a central concern, their focus shifts over time to the need for transparent communication from management. Interpersonal justice shows only one significant and unexpectedly negative effect on AMC roughly six months after the acquisition.

In an effort to reveal the reasons behind the negative effect of interpersonal justice and to test our hypotheses further, we conducted a post-hoc analysis, which revealed heterogeneity between bidder and target employees. The post-hoc analysis showed that bidder employees pay more attention to informational justice (adequate and timely information process) in $t_{1}$ than at a later stage. A reason might be that bidder employees tend to be initially rather curios about the development of the new firm than afraid of losing their jobs.

The post-hoc analysis showed that target employees pay more attention to procedural justice (a clear and fair decision-making process) in $t_{1}$ than at a later stage, as target employees tend to be initially more afraid of losing their status, their routines, and even their jobs. Put differently, since bidder employees’ jobs are usually safer, which leads to a better bargaining-position shortly after the acquisition announcement, they are at first more interested in clear-cut and precise communication about what is happening (informational justice). Procedural justice becomes also for bidder employees important in $t_{2}$, when bidder employees seek procedural justice. In $t_{2}$, when the firms' processes 
have begun to merge and the bidder employees’ work environment has begun to change, there might have been a stronger demand for procedural justice on the bidder side as well, as during that time some target employees’ work location changed to the bidder firm, and the product lines for testing devices were partially combined. As for the negative path-coefficient of interpersonal justice in the overall model, we find the underlying reason on the target side in $t_{2}$, for which we uncover a negative relationship, followed by a positive path in round $t_{3}$. We conclude that there is no clear relationship between interpersonal justice and AMC in our study. There might be an unobserved moderating variable — a situational factor — that determines whether interpersonal justice has a positive or a negative effect on the AMC.

Our paper contributes to both academics and practitioners. Our academic contribution is to support equity theory by showing that employees who perceive the presence of justice during and after a merger have a higher AMC. Finding a link between meeting the basic need for security in a fair manner and AMC builds on the equity theory of fair treatment (Adams, 1963; 1965). Our findings suggest that the equity theory is applicable also in our sample case of a cross border M\&A in the Japanese context. Taken together, the findings provide support that the impact of the sub-dimensions of justice changes as the post-integration period ages. We also extend equity theory by providing a theory-driven account of perceptions’ instability over time, so they need to be adjusted as the post-integration ages. We also show that there are differences between bidder and target employees’ perceptions, which can also be explained by this theoretical lens; employees do not just want to be treated fairly, but the kind of fairness they expect depends on whether they are from the target or the bidder side. The bidder employees value being informed, while target employees ask for process-related fairness. 
Our practical contribution is to show that employees measure their inputs against their outcomes. Employees who perceive that they are receiving fair treatment have a higher AMC. However, each of the sub-dimensions of justice affects employees’ AMC differently. Based on our findings, politeness and respect from management is a weak factor in explaining, encouraging, and systematically developing employees’ AMC to the merger process, as employees' expectations about management's behavior during and after a merger both differ and fluctuate. Interpersonal justice has less effect than procedural or informational justice, which requires more attention from management.

Turning to the limitations of our study, our empirical sample in a few cases has less than forty observations. Based on the rule of ten (Hair et al., 2014), an empirical sample should at least have ten times the number of observations than the maximum number of indicators or paths pointing at a particular construct. Since we used a reflective model that had a substantial Cronbach's $\alpha$ for every operationalized construct, there was no need; however, to remove indicators in order to meet the sample size requirements. Even given this limitation, we assume that our model is well-balanced in the given context.

A second limitation is related to the measures in this study, all of which were collected through self-reported surveys, increasing the risk of common method bias (Podsakoff, MacKenzie, \& Podsakoff, 2012). Third, we investigated a cross-border acquisition with a Japanese target firm, and we cannot assume that employees from other countries behave as Japanese employees do. For example, US employees may be more likely to leave the firm earlier than their Japanese counterparts would do after acquisition or their justice-related expectations may be higher. Hence, future research should analyze bidder and target employees separately using a more observations to deal with heterogeneity. Failure to do so might ultimately be a factor in the misinterpretation of empirical findings. We would also like to see longitudinal studies 
like that requested by Cartwright and Schoenberg (2006), which was not possible because the top management was not in favor of it. By conducting longitudinal studies, researchers would be able to control for the presence of underlying moderators, such as those we assume are affecting interpersonal justice.

This research, based on real-world data about a cross-border acquisition, offers new findings about employees’ perceptions of justice into the post-merger integration discussion. Its findings can help to increase the success rate of cross-border M\&A by helping managers meet the significant employee-related challenges of post-merger integrations. 
Table 2: Measurement models

\begin{tabular}{|c|c|c|c|}
\hline $\begin{array}{c}\text { Latent } \\
\text { Variable }\end{array}$ & Indicator & Reflective Measures & Source \\
\hline \multirow{4}{*}{ 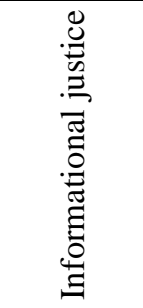 } & IJ1 & $\begin{array}{l}\text { The management... } \\
\text {... explains its decisions thoroughly }\end{array}$ & (Bies \& Moag, 1986) \\
\hline & IJ2 & ... reasonably explains its decisions & (Bies \& Moag, 1986) \\
\hline & IJ3 & ... seems to tailor its communications to your specific needs & $\begin{array}{l}\text { (Shapiro, Buttner, \& } \\
\text { Barry, 1994) }\end{array}$ \\
\hline & IJ4 & ... communicates details in a timely manner & (Shapiro et al., 1994) \\
\hline \multirow{4}{*}{ 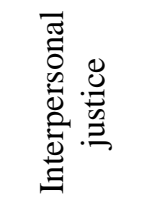 } & INJ1 & ... treats you politely & (Bies \& Moag, 1986) \\
\hline & INJ2 & ... treats you with dignity & (Bies \& Moag, 1986) \\
\hline & INJ3 & ... treats you with respect & (Bies \& Moag, 1986) \\
\hline & INJ4 & ... refrains from improper remarks or comments & (Bies \& Moag, 1986) \\
\hline \multirow{4}{*}{ 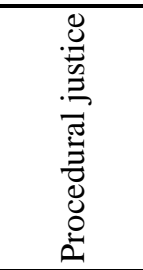 } & PJ1 & The decision-making process has been applied consistently. & (Leventhal, 1980) \\
\hline & PJ2 & The decision-making processes has been free of bias. & (Leventhal, 1980) \\
\hline & PJ3 & The decisions have been based on accurate information. & (Leventhal, 1980) \\
\hline & PJ4 & $\begin{array}{l}\text { The decision-making process has upheld ethical and moral } \\
\text { standards. }\end{array}$ & (Leventhal, 1980) \\
\hline \multirow{3}{*}{ 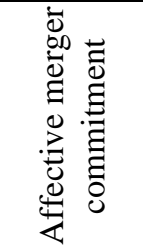 } & AMC1 & I believe in the value of this affiliation. & $\begin{array}{l}\text { (Herscovitch \& } \\
\text { Meyer, 2002) }\end{array}$ \\
\hline & AMC2 & This affiliation is a good strategy for my organization. & $\begin{array}{l}\text { (Herscovitch \& } \\
\text { Meyer, 2002) } \\
\end{array}$ \\
\hline & AMC3 & This affiliation serves an important purpose. & $\begin{array}{l}\text { (Herscovitch \& } \\
\text { Meyer, 2002) } \\
\end{array}$ \\
\hline
\end{tabular}

Notes: Items for organizational justice are taken from Colquitt (2001), but the table displays the original authors of the items.

Table 3: Quality criteria for the higher-order construct

\begin{tabular}{|c|c|c|c|c|c|c|c|c|c|c|}
\hline \multirow[b]{2}{*}{ HOC } & \multirow[b]{2}{*}{ LOC } & \multicolumn{3}{|c|}{$t_{1}$} & \multicolumn{3}{|c|}{$t_{2}$} & \multicolumn{3}{|c|}{$t_{3}$} \\
\hline & & $\begin{array}{l}\text { Path- } \\
\text { Coefficient }\end{array}$ & $\mathbf{f}^{2}$ & VIF & $\begin{array}{l}\text { Path- } \\
\text { Coefficient }\end{array}$ & $\mathbf{f}^{2}$ & VIF & $\begin{array}{l}\text { Path- } \\
\text { Coefficient }\end{array}$ & $\mathbf{f}^{2}$ & VIF \\
\hline \multirow{3}{*}{ 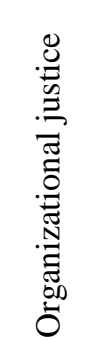 } & $\begin{array}{l}\text { Informational } \\
\text { justice }\end{array}$ & .26 & 2.29 & 1.75 & $.47 * * *$ & 8.07 & 2.17 & $.64^{* * *}$ & 9.79 & 2.13 \\
\hline & $\begin{array}{l}\text { Interpersonal } \\
\text { justice }\end{array}$ & -.07 & 0.15 & 1.76 & $-.46 * * *$ & 8.24 & 2.05 & .21 & 1.02 & 2.11 \\
\hline & $\begin{array}{l}\text { Procedural } \\
\text { justice }\end{array}$ & $.85^{* * *}$ & 18.51 & 2.33 & $.89 * * *$ & 23.48 & 2.64 & .25 & 1.11 & 2.91 \\
\hline
\end{tabular}

Notes: Bootstrapping results are marked with asterisks according to the significance level (i.e., 1,000 subsamples; no sign change option).

$* * *$ Significant at $1 \%$

Table 4: Structural model, explained variance, and predictive relevance

\begin{tabular}{|c|c|c|c|c|c|c|c|c|c|}
\hline \multirow{2}{*}{$\begin{array}{c}\text { Target } \\
\text { Construct }\end{array}$} & \multicolumn{3}{|c|}{$t_{1}$} & \multicolumn{3}{|c|}{$t_{2}$} & \multicolumn{3}{|c|}{$t_{3}$} \\
\hline & OJ $\rightarrow$ AMC & $Q^{2}$ & $R^{2}$ & $\mathrm{OJ} \rightarrow \mathrm{AMC}$ & $Q^{2}$ & $R^{2}$ & $\mathrm{OJ} \rightarrow \mathrm{AMC}$ & $Q^{2}$ & $R^{2}$ \\
\hline $\begin{array}{c}\text { Affective } \\
\text { merger } \\
\text { commitment }\end{array}$ & $.53 * * *$ & .21 & .29 & $.61^{* * *}$ & .28 & .37 & $.57 * * *$ & .23 & .33 \\
\hline
\end{tabular}

Notes: Bootstrapping results are marked with asterisks according to the significance level (i.e., 1,000 subsamples; no sign change option).

$* * *$ Significant at $1 \%$ 
Table 5: Quality criteria for the measurement models

\begin{tabular}{|c|c|c|c|c|c|c|c|c|c|c|c|c|c|c|c|c|}
\hline \multirow[b]{2}{*}{ Construct } & \multirow[b]{2}{*}{ Indicator } & \multicolumn{5}{|c|}{$t_{1}$} & \multicolumn{5}{|c|}{$t_{2}$} & \multicolumn{5}{|c|}{$t_{3}$} \\
\hline & & Loading & CR & $\begin{array}{l}\text { Cron- } \\
\text { bach's } \alpha\end{array}$ & AVE & $\begin{array}{l}\text { Fornell- } \\
\text { Larcker }\end{array}$ & Loading & CR & $\begin{array}{l}\text { Cron- } \\
\text { bach's } \alpha\end{array}$ & AVE & $\begin{array}{l}\text { Fornell- } \\
\text { Larcker }\end{array}$ & Loading & CR & $\begin{array}{l}\text { Cron- } \\
\text { bach's } \alpha\end{array}$ & AVE & $\begin{array}{l}\text { Fornell- } \\
\text { Larcker }\end{array}$ \\
\hline \multirow{4}{*}{$\begin{array}{c}\text { Informational } \\
\text { justice }\end{array}$} & IJ1 & $0.89 * * *$ & \multirow{4}{*}{0.92} & \multirow{4}{*}{0.88} & \multirow{4}{*}{0.74} & \multirow{4}{*}{$\checkmark$} & $0.94 * * *$ & \multirow{4}{*}{0.96} & \multirow{4}{*}{0.94} & \multirow{4}{*}{0.85} & \multirow{4}{*}{$\checkmark$} & $0.91 * * *$ & \multirow{4}{*}{0.95} & \multirow{4}{*}{0.93} & \multirow{4}{*}{0.84} & \multirow{4}{*}{$\checkmark$} \\
\hline & IJ2 & $0.83^{* * *}$ & & & & & $0.92 * * *$ & & & & & $0.93 * * *$ & & & & \\
\hline & IJ3 & $0.88 * * *$ & & & & & $0.92 * * *$ & & & & & $0.90 * * *$ & & & & \\
\hline & IJ4 & $0.84 * * *$ & & & & & $0.92 * * *$ & & & & & $0.91^{* * *}$ & & & & \\
\hline \multirow{4}{*}{$\begin{array}{l}\text { Interpersonal } \\
\text { justice }\end{array}$} & INJ1 & $0.95^{* * *}$ & \multirow{4}{*}{0.95} & \multirow{4}{*}{0.92} & \multirow{4}{*}{0.82} & \multirow{4}{*}{$\checkmark$} & $0.95^{* * *}$ & \multirow{4}{*}{0.96} & \multirow{4}{*}{0.94} & \multirow{4}{*}{0.84} & \multirow{4}{*}{$\checkmark$} & $0.95^{* * *}$ & \multirow{4}{*}{0.96} & \multirow{4}{*}{0.95} & \multirow{4}{*}{0.87} & \multirow{4}{*}{$\checkmark$} \\
\hline & INJ2 & $0.94 * * *$ & & & & & $0.96 * * *$ & & & & & $0.96 * * *$ & & & & \\
\hline & INJ3 & $0.92 * * *$ & & & & & $0.94 * * *$ & & & & & $0.95 * * *$ & & & & \\
\hline & INJ4 & $0.80 * * *$ & & & & & $0.81^{* * *}$ & & & & & $0.86^{* * *}$ & & & & \\
\hline \multirow{4}{*}{$\begin{array}{l}\text { Procedural } \\
\text { justice }\end{array}$} & PJ1 & $0.80 * * *$ & & & & & $0.88^{* * *}$ & & & & & $0.88^{* * *}$ & & & & \\
\hline & PJ2 & $0.89 * * *$ & 091 & 07 & כ7 0 & 1 & $0.87 * * *$ & רם 0 & 000 & 074 & $x$ & $0.92^{* * *}$ & & & & 1 \\
\hline & PJ3 & $0.89 * *$ & 0.91 & 0.07 & 0.75 & , & $0.89 * * *$ & 0.92 & 0.00 & 0.14 & & $0.93 * * *$ & 0.53 & Sד. & 0.03 & 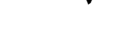 \\
\hline & PJ4 & $0.83^{* * *}$ & & & & & $0.80 * * *$ & & & & & $0.91^{* * *}$ & & & & \\
\hline Affective & AMC1 & $0.94 * * *$ & & & & & $0.96 * * *$ & & & & & $0.92 * * *$ & & & & \\
\hline merger & AMC2 & $0.94 * * *$ & 0.95 & 0.91 & 0.85 & $\checkmark$ & $0.94 * * *$ & 0.94 & 0.90 & 0.84 & $\checkmark$ & $0.94 * * *$ & 0.92 & 0.88 & 0.80 & $\checkmark$ \\
\hline commitment & AMC3 & $0.88 * * *$ & & & & & $0.84^{* * *}$ & & & & & $0.83^{* * *}$ & & & & \\
\hline
\end{tabular}

Notes: Bootstrapping results (i.e., 1,000 subsamples; no sign change option) are marked with asterisks according to the significance level.

*** Significant at $1 \%$ 
Table 6: Multi-group analysis of the higher-order construct

\begin{tabular}{|c|c|c|c|c|c|c|c|c|c|c|c|c|c|}
\hline \multirow[b]{2}{*}{ Construct } & \multirow[b]{2}{*}{$\begin{array}{c}\text { Lower-Order } \\
\text { Construct }\end{array}$} & \multicolumn{4}{|c|}{$t_{1}$} & \multicolumn{4}{|c|}{$t_{2}$} & \multicolumn{4}{|c|}{$t_{3}$} \\
\hline & & $\begin{array}{l}\text { Path } \\
\text { Coefficient } \\
\text { Bidder } \\
\end{array}$ & $\begin{array}{l}\text { Path } \\
\text { Coefficient } \\
\text { Target }\end{array}$ & T-Value & P-Value & $\begin{array}{l}\text { Path } \\
\text { Coefficient } \\
\text { Bidder }\end{array}$ & $\begin{array}{l}\text { Path } \\
\text { Coefficient } \\
\text { Target }\end{array}$ & T-Value & P-Value & $\begin{array}{l}\text { Path } \\
\text { Coefficient } \\
\text { Bidder }\end{array}$ & $\begin{array}{l}\text { Path } \\
\text { Coefficient } \\
\text { Target } \\
\end{array}$ & T-Value & P-Value \\
\hline \multirow{3}{*}{ 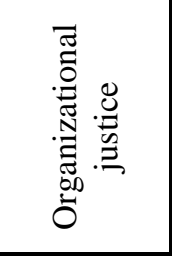 } & \begin{tabular}{|c|}
$\begin{array}{c}\text { Informational } \\
\text { justice }\end{array}$ \\
\end{tabular} & $.87 * *$ & -0.36 & 2.26 & .03 & 0.35 & $.86^{* *}$ & .72 & .47 & $.73^{* *}$ & .44 & 0.60 & .55 \\
\hline & \begin{tabular}{|c|} 
Interpersonal \\
justice
\end{tabular} & .24 & -0.11 & 0.70 & .49 & -0.50 & -.64 & .14 & .89 & .10 & $.69 * *$ & 1.27 & .21 \\
\hline & $\begin{array}{c}\text { Procedural } \\
\text { justice }\end{array}$ & -.08 & $1.21 * * *$ & 2.28 & .03 & $1.01 * * *$ & $.61^{* *}$ & .52 & .60 & .21 & .02 & 0.38 & .70 \\
\hline
\end{tabular}

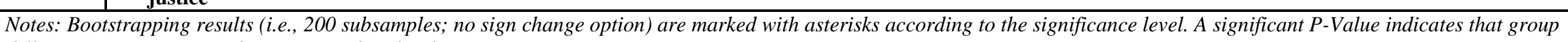
differences are present at the corresponding level.

*** Significant at $1 \%$

** Significant at $5 \%$

Table 7: Multi-group analysis of the target construct (OJ $\rightarrow$ AMC)

\begin{tabular}{|c|c|c|c|c|c|c|c|c|c|c|c|c|}
\hline \multirow[b]{2}{*}{ Construct } & \multicolumn{4}{|c|}{$\overline{t_{1}}$} & \multicolumn{4}{|c|}{$t_{2}$} & \multicolumn{4}{|c|}{$t_{3}$} \\
\hline & $\begin{array}{l}\text { Path } \\
\text { Coefficient } \\
\text { Bidder }\end{array}$ & $\begin{array}{l}\text { Path } \\
\text { Coefficient } \\
\text { Target }\end{array}$ & T-Value & P-Value & $\begin{array}{l}\text { Path } \\
\text { Coefficient } \\
\text { Bidder }\end{array}$ & $\begin{array}{l}\text { Path } \\
\text { Coefficient } \\
\text { Target }\end{array}$ & T-Value & P-Value & $\begin{array}{l}\text { Path } \\
\text { Coefficient } \\
\text { Bidder }\end{array}$ & $\begin{array}{l}\text { Path } \\
\text { Coefficient } \\
\text { Target }\end{array}$ & T-Value & P-Value \\
\hline $\begin{array}{c}\text { Affective } \\
\text { merger } \\
\text { commitment }\end{array}$ & $.53^{* * *}$ & $.55^{* * *}$ & .05 & .96 & $.62 * * *$ & $.31^{* *}$ & 1.12 & .26 & $.60^{* * *}$ & $.48 * * *$ & .87 & .39 \\
\hline
\end{tabular}

Notes: Bootstrapping results (i.e., 200 subsamples; no sign change option) are marked with asterisks according to the significance level.

*** Significant at $1 \%$

** Significant at 5\% 


\section{References}

Adams, J. S. (1963). Towards an understanding of inequity. The Journal of Abnormal and Social Psychology, 67(5), 422.

Adams, J. S. (1965). Inequity in social exchange. In L. Berkowitz (Ed.), Advances in Experimental Social Psychology (Vol. 2, pp. 267-299). New York: Academic Press.

Allen, N. \& Meyer, J. (1996). Affective, Continuance, and Normative Commitment to the Organization: An examination of construct validity. Journal of vocational behavior, 49, 252-276.

Ambrose, M. L. \& Schminke, M. (2009). The role of overall justice judgments in organizational justice research: A test of mediation. Journal of Applied Psychology, 94(2), 491.

Appelbaum, S. H., Serena, M., \& Shapiro, B. T. (2004). Generation X and the Boomers: Organizational myths and literary realities. Management Research News, 27(11/12), 1-28.

Becker, J.-M., Klein, K., \& Wetzels, M. (2012). Hierarchical latent variable models in PLS-SEM: Guidelines for using reflective-formative type models. Long Range Planning, 45(5-6), 359-394.

Bies, R. J. \& Moag, J. S. (1986). Interactional justice: Communication criteria of fairness. Research on Negotiation in Organizations, 1(1), 43-55.

Boateng, A., Qian, W., \& Tianle, Y. (2008). Cross-border M\&As by Chinese firms: An analysis of strategic motives and performance. Thunderbird International Business Review, 50(4), 259-270.

Buitendach, J. H., \& De Witte, H. (2005). Job insecurity, extrinsic and intrinsic job satisfaction and affective organisational commitment of maintenance workers in a parastatal. South African Journal of Business Management, 36(2), 27-37.

Cartwright, S. \& Schoenberg, R. (2006). Thirty years of mergers and acquisitions research: Recent advances and future opportunities. British Journal of Management, 17, 1-5.

Chatzkel, J. \& Ng, A. W. (2013). The Emergence of contemporary Chinese enterprise: The heterogeneity of national culture, corporate controls and integration approaches in M\&As. Thunderbird International Business Review, 55(5), 593608.

Chawla, A. \& Kelloway, K. E. (2004). Predicting openness and commitment to change. Leadership \& Organization Development Journal, 25(6), 485-498.

Cheung, G. W. (2008). Testing equivalence in the structure, means, and variances of higher-order constructs with structural equation modeling. Organizational Research Methods, 11(3), 593-613.

Chin, W. W. \& Newsted, P. R. (1999). Structural equation modeling analysis with small samples using partial least squares. In R. H. Hoyle (Ed.), Statistical Strategies for Small Sample Research (pp. 307-341). Thousand Oaks: Sage.

Citera, M., \& Rentsch, J. R. (1993). "Is there Justice in Organizational Acquisitions? The Role of Distributive and Procedural Fairness in Corporate Acquisitions,” in R. Cropanzano (ed.), Justice in the Workplace: Approaching Fairness in Human Resource Management. Hillsdale, NJ: Lawrence Erlbaum, 211-30.

Cohen-Charash, Y. \& Spector, P. E. (2001). The Role of justice in organizations: A meta-analysis. Organizational Behavior and Human Decision Processes, 86(2), 278-321. doi: http://dx.doi.org/10.1006/obhd.2001.2958 
Colquitt, J. A. (2001). On the dimensionality of organizational justice: A construct validation of a measure. Journal of Applied Psychology, 86(3), 386-400.

Colquitt, J. A., Conlon, D. E., Wesson, M. J., Porter, C. O. L. H., \& Ng, K. Y. (2001). Justice at the millennium: A meta-analytic review of 25 years of organizational justice research. Journal of Applied Psychology, 86(3), 425.

Colquitt, J. A., Greenberg, J., \& Zapata-Phelan, C. P. (2005). What is organizational justice? A historical overview. Handbook of Organizational Justice, 1, 3-58.

Colquitt, J. A. \& Shaw, J. C. (2005). How should organizational justice be measured. Handbook of Organizational Justice, 1, 113-152.

Dauber, D. (2009). Mergers and acquisitions, integration and culture: What we have learned and failed to learn in the past ten years. Paper presented at the Conference of the International Association of Cross-Cultural Competence and Management (IACCM) and CEMS Doctoral Seminar, Vienna, Austria.

Dick, R., Ullrich, J., \& Tissington, P. (2006). Working under a black cloud: How to sustain organizational identification after a merger. British Journal of Management, 17, 69-79.

Ellis, K. M., Reus, T. H., \& Lamont, B. T. (2009). The effects of procedural and informational justice in the integration of related acquisitions. Strategic Management Journal, 30(2), 137-161.

Faulkner, D., Teerikangas, S., \& Joseph, R. J. (Eds.). (2012). The handbook of mergers and acquisitions. Oxford University Press.

Fornell, C. G. \& Larcker, D. F. (1981). Structural equation models with unobservable variables and measurement error: Algebra and statistics. Journal of Marketing Research, 18(3), 328-388.

Gunkel, M., Schlaegel, C., Rossteutscher, T., \& Wolff, B. (2014). The human aspect of cross-border acquisition outcomes: The role of management practices, employee emotions, and national culture. International Business Review, 1-15. doi: 10.1016/j.ibusrev.2014.09.001

Hair, J. F., Hult, G. T. M., Ringle, C. M., \& Sarstedt, M. (2014). A Primer on Partial Least Squares Structural Equation Modeling (PLS-SEM). Thousand Oaks: Sage.

Hair, J. F., Ringle, C. M., \& Sarstedt, M. (2011a). PLS-SEM: Indeed a silver bullet. Journal of Marketing Theory and Practice, 19(2), 139-151.

Hair, J. F., Ringle, C. M., \& Sarstedt, M. (2011b). The use of partial least squares (PLS) to address marketing management topics: From the special issue guest editors. Journal of Marketing Theory and Practice, 19(2), 135-138.

Hair, J. F., Sarstedt, M., Pieper, T. M., \& Ringle, C. M. (2012). The use of partial least squares structural equation modeling in strategic management research: A review of past practices and recommendations for future applications. Long Range Planning, 45(5), 320-340.

Hair, J. F., Sarstedt, M., Ringle, C. M., \& Mena, J. A. (2012). An assessment of the use of partial least squares structural equation ,odeling in marketing research. Journal of the Academy of Marketing Science, 40(3), 414-433.

Henseler, J., Ringle, C. M., \& Sinkovics, R. R. (2009). The use of partial least squares path modeling in international marketing. In R. R. Sinkovics \& P. N. Ghauri (Eds.), Advances in International Marketing (Vol. 20, pp. 277-320). Bingley: Emerald.

Herscovitch, L. \& Meyer, J. P. (2002). Commitment to organizational change: Extension of a three-component model. Journal of Applied Psychology, 87(3), 474.

Hulland, J. (1999). Use of partial least squares (PLS) in strategic management research: A review of four recent studies. Strategic Management Journal, 20(2), 195-204. 
Jones, D. A. \& Martens, M. L. (2009). The mediating role of overall fairness and the moderating role of trust certainty in justice-criteria relationships: The formation and use of fairness heuristics in the workplace. Journal of Organizational Behavior, 30(8), 1025-1051.

Jöreskog, K. G. (1982). The LISREL approach to causal model-building in the social sciences. In H. Wold \& K. G. Jöreskog (Eds.), Systems under Indirect Observation, Part I (pp. 81-100). Amsterdam: North-Holland.

Judge, T. A. \& Colquitt, J. A. (2004). Organizational justice and stress: The mediating role of work-family conflict. Journal of Applied Psychology, 89(3), 395.

Keil, M., Saarinen, T., Tan, B. C. Y., Tuunainen, V., Wassenaar, A., \& Wei, K.-K. (2000). A cross-cultural study on escalation of commitment behavior in software projects. MIS Quarterly, 24(2), 299-325.

Klendauer, R. \& Deller, J. (2009). Organizational justice and managerial commitment in corporate mergers. Journal of Managerial Psychology, 24(1), 29-45.

Knilans, G. (2009). Mergers and acquisitions: Best practices for successful integration. Employment Relations Today, 35(4), 39-46.

Leventhal, G. S. (1980). What should be done with equity theory? New approaches to the study of fairness in social relationship. In K. Gergen, M. Greenberg, \& R. Willis (Eds.), Social exchange: Advances in theory and research (pp. 27-55). New York: Plenum Press.

Lind, E. A. (2001). Fairness heuristic theory: Justice judgments as pivotal cognitions in organizational relations. Advances in Organizational Justice, 56, 88.

MacKenzie, S. B., Podsakoff, P. M., \& Jarvis, C. B. (2005). The problem of measurement model misspecification in behavioral and organizational research and some recommended solutions. Journal of Applied Psychology, 90(4), 710.

Marzucco, L., Marique, G., Stinglhamber, F., De Roeck, K., \& Hansez, I. (2014). Justice and employee attitudes during organizational change: The mediating role of overall justice. Revue Européenne de Psychologie Appliquée/European Review of Applied Psychology, 64(6), 289-298.

Meyer, J. P., Stanley, D. J., Herscovitch, L., \& Topolnytsky, L. (2002). Affective, continuance, and normative commitment to the organization: A meta-analysis of antecedents, correlates, and consequences. Journal of vocational behavior, 61(1), 20-52.

Meyer, J. P. \& Allen, N. J. (1991). A three-component conceptualization of organizational commitment. Human Resource Management Review, 1(1), 61-89.

Mirc, N. (2014). Human impacts on the performance of mergers and acquisitions. Advances in Mergers and Acquisitions, 12, 1-31.

Mowday, R. T., Steers, R. M., \& Porter, L. W. (1979). The measurement of organizational commitment. Journal of Vocational Behavior, 14, 224-247.

Podsakoff, P. M., MacKenzie, S. B., \& Podsakoff, N. P. (2012). Sources of method bias in social science research and recommendations on how to control it. Annual Review of Psychology, 63, 539-569.

Purba, D.E., Oostrom, J.K., van den Molen, H.T., Born, Ph M. (2015). Personality and organizational citizenship behavior in Indonesia: The mediating effect of affective commitment. Asian Business \& Management, 14, 147-170.

Rafferty, A. E., \& Restubog, S. L. D. (2010). The Impact of Change Process and Context on Change Reactions and Turnover During a Merger. Journal of Management , 36 (5), 1309-1338.

Reinartz, W., Haenlein, M., \& Henseler, J. (2009). An empirical comparison of the efficacy of covariance-based and variance-based SEM. International Journal of Research in Marketing, 26, 332-344. doi: 10.1016/j.ijresmar.2009.08.001 
Ringle, C. M., Wende, S., \& Becker, J.-M. (2015). SmartPLS 3. Hamburg: SmartPLS. Retrieved from www.smartpls.com

Senn, L. (2008). Cultural clash in mergers \& acquisitions. Retrieved from http://www.senndelaney.com

Seo, M.-G. \& Hill, N. S. (2005). Understanding the human side of merger and acquisition: An integrative framework. The Journal of Applied Behavioral Science, 41, 422-443.

Shapiro, D. L., Buttner, E. H., \& Barry, B. (1994). Explanations: What factors enhance their perceived adequacy? Organizational Behavior and Human Decision Processes, 58(3), 346-368.

Thibaut, J. W., \& Walker, L. (1975). Procedural justice: A psychological analysis. Hillsdale, N.J: L. Erlbaum Associates.

Viegas - Pires, M. (2013). Multiple levels of culture and post M\&A integration: A suggested theoretical framework. Thunderbird International Business Review, 55(4), 357-370.

Wilson, B. (2010). Using PLS to investigate interaction effects between higher order branding constructs. In V. E. Vinzi, W. W. Chin, J. Henseler, \& H. Wang (Eds.), Handbook of Partial Least Squares: Concepts, Methods and Applications (Springer Handbooks of Computational Statistics Series, vol. II) (pp. 621-652). New York: Springer.

Wold, H. (1973). Nonlinear iterative partial least squares (NIPALS) modelling: Some current developments. Proceedings of the 3rd International Symposium on Multivariate Analysis. Dayton, $\mathrm{OH}$. 